\title{
XIX. On the penetration of water into stoppered and corked bottles sunk to a great depth in the sea
}

\author{
J. de C. Sowerby Esq. F.L.S.
}

To cite this article: J. de C. Sowerby Esq. F.L.S. (1828) XIX. On the penetration of water into stoppered and corked bottles sunk to a great depth in the sea, Philosophical Magazine Series 2, 4:20, 119-120, DOI: $10.1080 / 14786442808674739$

To link to this article: http://dx.doi.org/10.1080/14786442808674739

曲 Published online: 10 Jul 2009.

Submit your article to this journal $[\pi$

Џll Article views: 2

Q View related articles $₫$ 
a limit which, between the 15th and 17th degrees of south latitude, and on the sides of the Bolivian Andes, seldom descends below 17,100 feet above the sea.

The great mass of the eastern cordillera, situated north of the parallel of $17^{\circ} \mathrm{S}$. is likewise formed of the transition rocks above enumerated; the sienitic or crystalline rocks becoming more abundant on its northern prolongation. The schistose rocks here also abound in auriferous veins; and through the deep dells which intersect them, descend the numerous auriferous torrents, which empty themselves into the river Beni and its confluents, and give to the tropical district bordering on the river of Tipuacio (in the province of Larecaja), the fairest claim to the title of the El Dorado of the new world, from the great quantities of gold, which have been and are still collected from the alluvial deposits that form its banks.

I am, Gentlemen, yours, \&c.

June 25, 1828.

J. B. Pentitand.

XIX. On the Penetration of Water into stoppered and corked Bottles sunk to a greatDepth in the Sea. By J.DE C. SowerBY, Esq. F.L.S. \& c.

Dear Sir,

To Richard Taylor, Esq.

MANY papers having at different times appeared upon the popular paradox, a bottle filling with water when sunk to a great depth in the sea, however well it may have been corked and sealed, without any satisfactory explanation having been given, and seeing the subject resumed by Dr. Green, in your Philosophical Magazine for this month,-I am induced to send you my explanation of the phænomenon.

Dr. Green thinks that by proving (as others had done) that the water would not penetrate glass, he had reduced the question into very narrow limits; and that the water enters glass vessels through the "cork and all its coverings in consequence of the vast pressure of superincumbent water, in the same manner as blocks of wood are penetrated by mercury in the pneumatic experiment of the mercurial shower."

It may be concluded from recorded experiments, that wellfitted glass stoppers (by the bye, every chemist knows such are rarely to be obtained as will confine the vapour of nitric acid) will exclude the water; corks when properly protected will also prevent the water from entering. When mercury is made to pass through a block of wood by pneumatic pressure, it finds its way by the longitudinal tubes; such tubes do 
not exist in cork. My explanation is this ; cork is elastic, and by the pressure of the sea is readily condensed, and consequently much diminished in bulk, first that part out of the bottle where the sides are not protected by the neck, and then gradually the remaining length until the cork, separated entirely from the glass, affords a free passage for the water, unless the sealing or wrapper be of such a tenacious and ductile nature as to adhere to the glass and the cork so as to fill up the space that would otherwise be left, and yet not yield completely to the pressure; if it be brittle, it either separates from the glass, or cracks, or both, allowing a free passage to the water. Even pitch when cooled in the deep water would be very brittle and crach or separate from the bottle readily, and it would resume its former ductility and appearance upon returning through the warm surface : this and similar considerations will show how a trifling difference in closing the bottles may produce considerable differences in the results of the experiments. I remain, yours truly,

2, Mead Place, Lambeth, July 12, 1828.

J. DE C. Sowerby.

XX. Some further Remarks on Messrs. Tiedemann and Gmelin's Observations on the Acids of the Stomach. By Wм. Prout, M.D. F.R.S.*

TTHE observations of Messrs. Tiedemann and Gmelin on my paper published in the last Number of the Philosophical Magazine and Annals, seem to me to be intelligible only on the two following asșumptions. First, that the method employed was adopted at random and without any preliminary inquiry, and was intended to include every possible case; and secondly, that on the faith of this random method, I denied generally and under all circumstances the existence of every other acid except the muriatic acid, in the stomachs of animals. Now whether these assumptions can be fairly drawn from my paper, I, as an interested individual, can scarcely, perhaps, be admitted as competent to decide; but I can truly say at least, that I never intended that such inferences should be drawn, nor was aware that any thing had been stated to authorize them.

With respect to the first of these assumptions it may be said, that the nature of the gastric fluids, and especially the acid, had occasionally occupied my particular attention for many years; and that during the summer before my paper was published, I had set about the inquiry in earnest, and with the determi-

* Communicated by the Author.

nation, 